\title{
SOME ACCOUNT OF THE HISTORY OF THE TREATMENT OF SYPHILIS*
}

\author{
BY \\ J. JOHNSTON ABRAHAM \\ Senior Surgeon, London Lock Hospital
}

This paper is on the history of the treatment of syphilis, so I do not propose to go inte the vexed question of the origin of the disease, a subject which has divided medical historians into hostile camps for the last hundred years.

\section{The Epidemic at the Siege of Naples}

But whatever views one has about the origin, no one I . think disputes the fact that the first great epidemic of the disease swept Europe after the return of Columbus from America, and it was first noticed markedly during the so-called Siege of Naples by Charles VIII of France in 1495. At that time physicians obviously thought they were dealing with a new and strange disease, and they. were at first completely helpless in its treatment. So they fell back on regimen, diet, bleeding, purgation, alterants, the six non-naturals of Galen-all the traditional lore of the Middle Ages. They wrote weird prescriptions containing such things as Mithridatum and Theriac, the broth, or the burnt flesh, or the syrup of vipers. And their patients naturally grew worse and worse.

The disease was so contagious that it spread rapidly, extra-genitally, from victim to victim by contact, by kissing, by utensils, towels etc., for its venereal origin was not recognized at first. Its obvious manifestations, however, were on the skin ; it was looked upon as a skin disease; and as it somewhat resembled scabies, then a very prevalent complaint, some of the bolder spirits therefore began to treat it with the ointments used in scabies, impetigo, and similar skin complaints.

\section{"Unguentum Saracenicum"}

As it happened the most popular ointment used in the treatment of scabies was one recommended by Guy de Chauliac in his Grande Chirurgie, written in 1363-that is, of course, long before printing was

\footnotetext{
* An address to the Medical Society for the Study of Venereal Diseases, April 24, 1948.
}

D invented-and used in manuscript all over Europe as the standard work. This preparation was called "Unguentum Saracenicum" from its Arabian origin, and the prescription as given by Astruc ( $A$ Treatise on the Venereal Disease (Barrowby's translation), London, 1937, vol. 1, p. 195), was :

$\begin{array}{lr}\text { Euphorb. et lithargyri } & \text { ana lib : (1 } \\ \text { Staph. agriæ } & \text { quartam }:\left(\begin{array}{l}1 \\ 1\end{array}\right) \\ \text { Argenti vivi } & \text { quartam : (1) } \\ \text { Axungiæ porci veteris } & \text { lib : (1) }\end{array}$

Incorporando in mortario, fiat unguentum de quo aeger inungat se semel in septimanâ.

Euphorbium is a gum-resin, litharge is yellow oxide of lead, staphis agria is wild delphinium (larkspur), argentum vivum is, of course, mercury, and axungiæ porci veteris is pigs' grease. The instructions are that the sick man should inunct himself once a week with this preparation.

From one point of view this prescription is probably the most important ever written. It contains one-ninth part mercury, and it is due to that-happy accident that the specific which was used for the next four hundred years was so speedily, almost miraculously discovered-for mercury was the only drug of any value in this dread disease for four hundred and fifteen years, until Ehrlich introduced arsphenamine in 1910.

Guy de Chauliac was careful to point out that the ointment was not without risk. It salivated the victim if used too long or too frequently. It gave him pains in his belly, and it loosened his teeth. The physicians who used Guy's manuscript as a textbook were, therefore, very careful. They used the ointment gently, slowly, and sparingly. Not so the quacks, who soon got on to the remedy. The disease was so prevalent that there were not enough physicians to treat it ; ; $^{-}$butchers, sow-gelders, farriers, and itinerant mountebanks travelling from country to country, used the ointment freely, scoring rapid and startling success in clearing signs as well as symptoms. The foul 
ulcers, the violent bone pains, the severe headaches, the eye symptoms, disappeared as if by magic. And the itinerant quacks passed on before the inevitable relapses and the not infrequent deaths from over treatment.

\section{Dangers of Mercury}

Obviously mercury was a dangerous drug, and physicians now remembered that Dioscorides, the great 'classical authority on materia medica, in A.D. 60 stated that it rotted the guts; they remembered that Galen (A.D. 131-200) supported him in this view, and that later writers like Oribasius (A.D. 325-403) and Paulus Aeginata (A.D. 607-690) did the same (Astruc, op. cit., vol. 1, p. 143). None the less, in this new disease they had to use it, and so they tried every method to make it less poisonous. It was noticed, for instance, that if mercury was mixed with saliva a fine emulsion was produced; and so in the prescription of John of Vigo for his "Neapolitan ointment," which superseded that of Guy de Chauliac, we'find the words " argentum vivum extinctum cum saliva" (Opera Domi Joannis de Vigo, Lyons, 1540). This was supposed to make it less poisonous.

Mercury was then given in three ways :

(1) by inunction with a mercurial liniment on different parts of the body daily, for a period of fifteen to thirty days ;

(2) by mercurial plasters applied every two or three days. A favourite was Emplastrum de Vigo ;

(3) by fumigations in a hot cabinet with cinnabar. (crude mercury sulphide), frankincense, mastich, or juniper gum.

The trouble with mercury, then as now, is that the dosis curativa and the dosis tolerata are too close ; and it is very easy to make the cure worse than the disease.

That is what happened as the result of the early and too enthusiastic use of the metal.

Ulrich von Hutten, Mercury, and Guaiacum

The first sufferer to rebel in print against the treatment was Ulrich von Hutten, a German poet and a friend of the great scholar Erasmus. He said he had had six treatments in eight years. Each day of his treatment he had one to four inunctions, he was kept in bed in one room at a high temperature, and he was heavily clothed to produce sweating. This went on for twenty to thirty days, during which he was not allowed out of his room. According to him, his jaws, tongue, lips, and palate became ulcerated, his gums swelled, his teeth loosened and fell out. Saliva dribbled continuously from his mouth, and his breath became intolerably fœtid. The whole apartment where he was being treated stank intolerably, and the cure was so hard to suffer, he felt he would rather choose to die than to submit to it further. Yet in spite of all these treatments he says he relapsed. It was then that he heard of guaiacum.

Guaiacum came from the wood of a tree, either the lignum vita or the lignum sanctum, both found in the West Indies. This wood was considered sacred by the natives, who themselves used it in the treatment of syphilis. Samples reached Spain from Hispaniola in 1517, and it was said to have cured two thousand people there in the next three years. It received its greatest advertisement, however, in 1519 when the poet Ulrich von Hutten published his famous work, De Morbi Gallici Curatione per Administrationem Ligni Guaiaci ("Aphrodisiacus," Venice, 1599), describing the tortures he had suffered under mercury, and the blessed relief he obtained when cured by guaiacum. Physicians, scared by their experience with mercury, took to it eagerly, and Fracastor, who invented the name syphilis, seems to have used it from 1525 onwards.

Originally only decoctions of the bark or the wood were used; the gum came into use much later ("London Pharmacopœia," 1677).

At first the drug was received with a burst of enthusiasm. Fracastor in his poem describes how the shepherd Syphilus was cured by it, after Apollo, who struck him with the disease as a punishment for impiety, had relented. But enthusiasm began to die down as failure after failure came, and it was found not to be as effective in controlling symptoms as the drzaded mercury. And Ulrich von Hutten, who was largely responsible for its introduction to western Europe, died miserably of tertiary syphilis at the age of thirty-five in spite of his reputed cure.

\section{Other Drugs}

It was then that another drug came into fashion, "China root," Smilax sinensis, brought by the Portuguese from Goa in 1535 ; and for a while, it largely supplanted guaiacum.

It too, however, presently fell into disfavour and, mainly owing to Fallopius (De Morbo Gallico, Padua, 1564), guaiacum came back, especially after it was said to have cured the Emperor Charles V of rheumatism. This reputation, and the dread of mercury, kept guaiacum in the pharmacopœia of every nation in Europe for the next four hundred years; and it was still official in the British Pharmacopcia of 1914, combined with calomel and antimony in " Plummer's pill," then a favourite anti-syphilitic preparation. It is still used with sulphur in "Chelsea Pensioner," owing to its old reputation as an anti-rheumatic.

Yet another drug which was introduced a little 
later than Fracastor's time was sarsaparilla, prepared from the root of a South American plant, Smilax ornata. It, too, has had a long. run in popular favour as a "blood purifier." It is still sold at fairs by itinerant quacks. It, too, was until 1898 official in the British Pharmacopœia in "Decoct. Sarsæ Co. Con." Sassafras officinale was another American plant used. It also survives with sarsaparilla and guaiacum in "Decoct. Sarsæ Co., B.P.C."

Such then were the drugs-mercury, guaiacum, sarsaparilla, sassafras-which were employed in the treatment of this fell malady for three hundred and sixty years, before anything else was added to our armamentarium.

Tradition in medicine dies hard. The old treat: ment of sweating patients heavily for days, and at the same time giving copious fluid drinks containing antiluetic drugs like guaiacum and sarsaparilla, did not disappear until comparatively recently. It was still official in the Army textbook of Keogh and Leishman in 1908. When I was a house surgeon at the Lock Hospital we had a small chamber, kept heated to over $80^{\circ}-\mathrm{F}$., where we treated patients with Zittmann's decoctions No. 1 and No. 2 (Johann Frederick Zittmann, 1671-1757) (see Goodman, 1944). No. 1, the strong decoction, contained sarsaparilla, calomel, cinnabar, anise, fennel, senna, and liquorice. It was taken in quart doses, warm. No. 2, the weak decoction, was made from the dregs of No. 1, to which were added lemon peel and cardamoms. It was, taken in quart doses, cold. The treatment lasted for ten days.

Only cases of malignant syphilis, old malarial cases, and cachectic patients who resisted all other forms of treatment were given this drastic course. It sometimes seemed surprisingly useful. At any rate, some of them recovered when every other form of treatment failed; and it was used in malignant cases up to the time arsphenamine was introduced.

\section{Paracelsus and his Experiments with Metals}

Classical writers like Dioscorides considered mercury taken internally to be a deadly poison. This view was still held as late as 1530 by orthodox physicians like Fracastor and Montanus. But unorthodox people like Paracelsus (1490-1541) were now beginning to practise. (Paracelsus publicly burnt the works of Galen to show his contempt for them.) People like him refused to accept tradition; and one, Peter Matthiolus, as early as 1536 actually had the temerity to prescribe hydrarg. ox. rub., 5 gr., as a pill to be taken internally (Astruc, op. cit., vol. 1, p. 207). Next year Barbarossa, the famous Algerian pirate, hearing that Francis I, King of France and a contemporary of our Henry VIII, had unfortunately acquired syphilis, sent him, as a chivalrous gesture from one enemy in trouble to another, a present of pills made from crude mercury, rhubarb, amber, musk, and flour (Astruc, op. cit., vol. 1, p. 208). As a consequence the pill treatment was soon in full swing. Pills-were much easier to use and were not messy like the older forms of treatment. They rapidly became popular.

Paracelsus tried them, but, not content with mercury, experimented with other metals. When, however, he had poisoned thirty monks in one monastery with antimony he, too, returned to mercury.

\section{Mercury Pills-Their Rise and Fall}

Over enthusiasm in the use of pills soon brought on all the old disasters that followed excessive inunction. The great Fallopius (1564) thundered against the use of pills as he had against inunction, recommending a return to guaiacum. Jean Fernel, the most famous physician in France in 1579, and the last great advocate of guaiacum, maintained that nearly all the late symptoms of syphilis were really due to mercurial poisoning-a view that recurs again and again throughout the next two centuries (see Aphrodisiacus). The fear of the indiscriminate use of mercury, indeed, became so great that in this country the surgeons at St. Bartholomew's Hospital were not allowed to prescribe it internally, and as late as the reign of Charles I we find Harvey complaining bitterly to the governors of the hospital that the surgeons were actually disobeying this ruling.

\section{Confusion of Syphilis with Gonorrhoea}

To make things still more confusing and much worse, Paracelsus began to call syphilis "French gonorrhœa," and to maintain that the two diseases were identical. In syphilis there was a sore on the outside. In gonorrhœa the sore was inside and caused the discharge. With our knowledge today this sounds fantastic; but it is easy to see that before modern microscopy a man getting gonorrhœa after one intercourse, and some weeks later developing a chancre without having taken any further risks, might think the two symptoms were the result of one disease. This heresy in fact lasted for three hundred years ; Ambroise Paré, Sydenham, and the great John Hunter believed it; and physicians generally accepted the dogma that there was only one venereal disease. As a result of this belief, the unfortunate sufferers from gonorrhœa were treated for over three centuries with mercurywith all its attendant risks-until Phillipe Ricord, 
as late as 1838 , proved the falsity of the belief to a world that had refused to believe Benjamin Bell in 1793.

$$
\text { "Good Spitting" }
$$

Mercuiry was supposed to act by stimulating the flow of pituita or phlegm. This phlegm carried away the venereal poison, and so patients were salivated. And, if they lost their teeth in the process, it was pointed out to them that that was sure evidence they had been adequately treated. Three pints of saliva in the day was considered a good average. Patients spat into pewter bowls graduated in pints and the physician on his rounds examined the pots. 'If the quantity of saliva was too little the dose of mercury was increased. Treatment was stopped when the mouth became too ulcerated, and decoctions of a mixture of guaiacum, china root, sarsaparilla, and sassafras were given, thus combining the best of two worlds.

Even in the eighteenth century, however, there were physicians who maintained it was not necessary to go to such lengths in producing salivation, but they were mostly voices crying in the wilderness.

\section{Thomas Dover}

It was inevitable, therefore, that anyone who could prescribe mercury in a way that did not produce the horribly foetid, smelling mouths of the salivated patient, would get an eager hearing. Thomas Dover (1660-1742), practised in Bristol, and that made him interested in one of Bristol's main industries at the beginning of the eighteenth century-privateering against the Spaniards. He actually sailed as captain of a ship in which he had a financial interest. It was on this voyage that he rescued Alexander Selkirk from Juan Fernandez, and so suggested to Daniel Defoe the story of Robinson Crusoe.

After he returned from his buccaneering adventures, by which he acquired several thousand pounds, he practised in Bristol and in London; and in 1732 , at the age of seventy, he published a work called The Ancient Physician's Legacy to his Country, in which he lauded the use of metallic mercury as a specific for every imaginable complaint ; he very carefully did not mention syphilis, but obviously used the metal for this complaint. The victims swallowed an ounce of liquid metallic mercury every day and voided it naturally. Patients were known to have swallowed as much as sixteen pounds of mercury during a treatment.

\section{$\therefore$. .... Elusive Quicksilver}

The thing became a rage. One gentleman found globules of mercury in his shoes, which his servant, on taking theth off, showed him. Two men came daily to the same tavern with their little bottles of quicksilver. Having swallowed it, they smoked their pipes and took a gill of wine. Afterwards the drawer (that is, the waiter) always found some little globules of mercury on the floor. He said it might have been spilt from their bottles, but rather believed it came from their backsides. During a dance at a public assembly, a lady was thought to have dropped her pearls, but her escort, on going to pick them up, found, much to the lady's confusion, they were globules of mercury.

In 1733 Daniel Turner, physician to the Lock Hospital, told the above stories in a violent attack on Dover in a work entitled The Ancient Physician's Legacy Impartially Surveyed; but the craze lasted well into the 1760 's, for William Blomfeild, surgeon to St. George's Hospital and the founder of the present Lock Hospital, also tried it in syphilis but found it inadequate.

\section{New Methods of Mercury Administration}

A new idea, and one that then rapidly spread, was the use of solutions of corrosive sublimate (liquor hydrarg. perchlor). This was popularized by Baron van Swieten (1700-1772), a pupil of Boerhaave, who founded the old Vienna School of Medicine. It was a clean, easily used method; it had Boerhaave's recommendation; and it appealed very much to Sir John Pringle, who mades it official in the British Army (see Jeanselme, " Histoire de la Syphilis," p. 284 ; and Boerhaave, 1753).

Through the long history of treatment the difficulty has always been the poisonous nature of mercury; and practitioners never stopped trying out methods of getting round this. One of the most ingenious was that of Peter Clare, a pupil of Percivall Pott. He published a little book in 1779 with a very long title : $A$ New and Easy Method of Curing the Lues Venerea by the Introduction of Mercury into the System through the Orifices of the Absorbent Vessels in the Inside of the Mouth. The method was to rub two grains of calomel inside the lips, and he got John Hunter-and also William Cruikshank, the discoverer of the lymphatic circulation-to recommend it. It was yet another example of an attempt to combat the fear that mercury produced, but it does not seem to have had much following.

The trouble was that most physicians still believed it was necessary to produce marked salivation to get rid of the venereal poison via the saliva, and they gave intensive short courses. Because the cases relapsed, physicians who said salivation was not necessary were not believed. It had not dawned on anyone that prolonged and 
continuous treatment was essential; and ptyalism non-essential.

\section{Mercury is Banished}

In Edinburgh the effects of mercurial poisoning were so dreaded during the eighteen-twenties that John Thompson, Professor of Surgery, refused to use it in practice ; he fell back on antiphlogistics, rest in bed, and sudorifics-including guaiacum and sarsaparilla-practically the treatment advocated by Fallopius three hundred years before. Sir $u$ illiam MacGregor made this treatment official in the Army, and the demise of mercury as a specific was once again pronounced (Jeanselme, op. cit., p. 320).

\section{Potassium Iodide}

Excitement spread throughout the profession when there appeared in the Lancet for 1835-6, a series of articles on a new drug which promised to do all that mercury did without the risk attached. Cases that had proved intractable to mercury were cured like magic. Old tertiary cases that nothing would touch cleared up. Gumniata melted away. The new drug was hailed as a cure-all, and everyone hastened to use it. The drug was introduced by William Wallace of Dublin. It was iodide of potash ; and only those who remember the claims made for " 606 " when it was introduced in 1910, and one injection was supposed to cure the disease, can have any idea of the excitement produced by this discovery. Wallace was an extraordinary man and, but for his untimely death from typhus, would have become world famous.

\section{Confused Ideas about Syphilis}

The extremely contagious nature of syphilis was a commonplace in Fracastor's time. The fifteenth and sixteenth centuries accepted the fact of its contagiousness at all stages of the disease. But the confusion introduced by linking it with gonorrhoa obscured the importance of infectivity, and Hunter thought that only the chancre was contagious.

Phillipe Ricord, who proved that syphilis and gonorrhœa were distinct diseases, was the first to differentiate syphilis into primary, secondary, and tertiary. Nevertheless, he too, made the same mistake as Hunter, teaching that the secondary lesions were not contagious. He believed this because he found he could not start fresh lesions in his syphilitic patients by scratching their skins and trying to inoculate the virus from mucous patches or condylomata. He was ignorant of the fact that it is almost impossible to do this in a syphilitic patient twelve days after the primary sore appears, because the skin of a syphilitic is by that time practically immune to any such attempt.

Wallace, of Dublin, who knew of Ricord's views, tested them out by inoculating healthy out-patients from the secondary eruptions of his syphilitic patients, and he soon proved that Ricord was wrong. He published his results in the Lancet early in 1837, and no one seems to have been in the least horrified at his method of proof.

Ricord, great man though he was, never quite admitted that he had been wrong about the noninfectivity of secondary lesions. He. refused to accept Wallace's results when they were brought to his notice. But the controversy over these auto-inoculations started another very curious episode in the history of the disease.

Soft sore had by now become more or less recognized as being somewhat different from hard chancre. Ricord himself had noticed that it was very readily inoculable all over the body, that it caused no constitutional symptoms, and that it could be cured by topical applications. But he still thought it was syphilitic.

In spite of Ricord's well-known views, Bassereau the elder stated in 1852 that, in his opinion, ulcus molle and syphilis were two distinct diseases. But the great Ricord would have none of this. Up to the time of his death he obstinately maintained the unity of the two diseases; and his prestige was so great that his opinion swayed the French medical world and even affected the English.

\section{Treatment by "Syphilization"}

The importance of this historically is that a very curious line of treatment developed from it called "syphilization." Jenner, it was pointed out, prevented smallpox by vaccinating with cow-pox. Therefore, why not try to prevent, modify, or cure syphilis by inoculation with the pus of soft sore, which according to Ricord, was an attenuated variety of syphilis. This line of treatment was started by Auzias-Turenne about 1850. His method was to inoculate his patients with pus from a soft sore, starting on the trunk and re-inoculating from each fresh soft sore again and again, ending up on the thighs and arms. In this way the sores grew smaller and smaller, until eventually they ceased to take. The victim was then thought to be immunized, or, if he were a syphilitic already, he was supposed to be cured. The process took on an average six months.

Auzias-Turenne suggested that prostitutes and anyone else liable to contract syphilis should be protected in this way. If one had unfortunately already got the disease it was supposed to shorten treatment and to prevent late recurrences. AuziasTurenne was such an enthusiast that he ignored the 
fact that there was an element of danger in this, as there was always the chance that a healthy person might get active syphilis by mistake. It was the same risk, of course, that people took who were purposely inoculated with the active virus of smallpox in the eighteenth century, before Jenner introduced vaccination in its place. But if the theory was correct it seemed quite a reasonable procedure (De la Syphilisation, Paris, 1853).

The Auzias-Turenne treatment was tried at the London Lock Hospital by Walter Coulson in 1865 (Coulson, 1869 ; Lane and Gascoyen, 1867), but it was quickly abandoned as useless. He found it practically impossible to re-inoculate syphilitics from mucous patches, and that inoculations from soft sore had no appreciable effect on the disease. Other observers found also that after as many as three hundred inoculations there was no immunity ; and gradually the treatment fell into disuse.

Auzias-Turenne, however, vehemently maintained and supported his views before the Medical Societies of Paris until the time of his death about 1878 . He was fanatical on the subject. After his death it was found that his whole body was covered with the scars of experimental inoculations he had done on himself - a pathetic proof of his faith in his own treatment.

So ended a curious and almost forgotten page in the history of this protean disease.

\section{The Nineteenth Century}

We now approach times that are more familiar to us. In 1861 Jonathan Hutchinson drew attention to his triad in congenital syphilis ; eighth-nerve deafness, Hutchinson's teeth, and interstitial keratitis.

Alfred Fournier in Paris had by then assumed the mantle of the great Ricord, and it was he who popularized the belief that the disease could be cured without severe salivation. He stressed the point that treatment should be slow, continuous, and spread over at least two years ; and taught that marriage was not safe for five years after infection (Fournier, 1890). Hutchinson strongly urged the same views in England, and it is to the influence of these two great men that the short intensive course of treatment previously in vogue came finally to be condemned.

But, of course, the two-year treatment was slow ; secondary signs disappeared tardily, and tertiary sequelæ, or what Hutchinson called " reminders" were very frequent. For this reason the proportion of hospital patients suffering from syphilis was much higher in Victorian times than it is today. In 1857 33 per cent. of Paget's out patients at St. Bartholomew's Hospital were venereal (Acton, 1870).
The intramuscular method of giving mercury was the only real advance in the technique of treatment towards the end of the nineteenth century. It originated in Vienna in 1886 (Jeanselme, op. cit., p. 374), was introduced into France soon after, and from 1889 onwards was popularized in England by military surgeons, particularly Lieut.Col. F. J. Lambkin (1905).

Subcutaneous injections of corrosive sublimate, which had been first introduced by Hebra in 1863 (Jeanselme, op. cit., p. 374), had now been given up as too painful; and intravenous injections were abandoned because they clotted the veins. At the Lock Hospital, however, Ernest Lane still gave intravenous cyanide of mercury, 20 minims of a 1 per cent. solution, three times weekly, as a routine for certain cases of early secondaries (Lane, 1896). He was still doing so when I was his house surgeon in 1907.

\section{Discovery of the Spirochæte}

We did not know then, but at this very time we were at the end of the dark ages of empirical treatment and on the verge of some of the greatest advances ever made in the diagnosis and treatment of this four-hundred-years-old disease. I can stillo remember the thrill that went round London earlyo in 1905 when we heard that Fritz Schaudinn and Eric Hoffmann had discovered the organism of syphilis, the Spirochata pallida. For a month or two we were unbelieving. So many claims had been made in the past that had turned out incorrect. But every time we took a smear from a chancre, and treated the slide with Indian ink, there were the spirochætes, curly, white (the dark-ground illumination method came later), and eventually we accepted the fact as proven.

\section{The Wassermann Reaction}

We had scarcely got used to this enormous aid to diagnosis when the next epoch-making advance came in 1906-the Wassermann reaction.

I was a house surgeon at the Harrow Road Hospital at the time, and Fleming, (now Sir Alexander Fleming) was the pathologist. The antigen at first was made from an extract of the liver of a dead syphilitic baby, and everyone seemed to think we had an unlimited supply of dead syphilitic babies at Harrow Road. Pathologists all wanted syphilitic liver. I was invited out to dinner, wooed like a film star, and asked eventually for a bit of liver-just one bit. For six months I was in clover. Then some unkind person found that human heart or ox heart did as well-and immediately my popularity ceased. That was in 1906. 


\section{Arsenicals}

We were treating patients then with one of the early arsenicals : atoxyl. This preparation, discovered by Bechamp in 1863, had been used with some success by Ehrlich against sleeping sickness, and so we tried it in syphilis. A course was one injection of atoxyl intramuscularly, followed by five of mercury intramuscularly ; then another of atoxyl, then five of mercury, and finally one of atoxyl. It .was called the 1.5.1.5.1. treatment: thirteen injections in thirteen weeks.

Atoxyl was an unfortunate name for an unfortunate drug, as it proved extremely toxic: several patients went completely blind and we had to stop hurriedly.

And then came arsphenamine in 1910. At first we used to cut down on a vein, introduce and tie in a cannula, and give the drug in $300 \mathrm{c.cm}$. of saline by gravity. Ehrlich claimed that, by this one injection, syphilis could be cured. He called it therapia sterilisans magna. He believed it, and for a time the world believed it with him, for the chancre, the rash, the Wassermann reaction, all cleared up like magic. People used to the old, slow, gradual disappearance of signs under mercury were astounded. Nothing like it had happened since Wallace and his iodide of potash in 1836. It was a miracle.

And then after a year or so came doubts. Cases supposed to be cured relapsed. Two injections, then three were given, and still relapses occurred.

By the time the war of 1914-1918 was over we were back again to two years' mercury, augmented by three courses of neoarsphenamine.

\section{Malaria Treatment of General Paresis}

The therapeutic value of malaria in general paresis was the next advance. It had been discovered by Wagner-Jauregg in Vienna in 1917 (Wagner-Jauregg, 1918) ; but we did not know of it until 1920 when the 1914-18 war was over.

\section{Modern Times}

The rest of my story is the story almost of yesterday. Bismuth came into use between 1920 and 1922, largely due to the work of Sazerac and Levaditi. For some years it had to fight its way into popularity against mercury. But I think we now are all agreed that it won the day, largely due to the fact that the curative dose is not nearly so close to the poisonous dose as it is with mercury.

Nevertheless I believe that there is still a place for mercury in treatment. When arsenic and bismuth fail, I have sometimes succeeded with mercury in making a positive blood Wassermann reaction negative.
Iodide of potash is also, I think, now unfairly neglected. It has its place in the treatment of gummatous lesions. Sometimes when a patient has an aneurysm, or what you suspect is a gumma of the upper jaw or a gummatous infiltration of the larynx, and the Wassermann is negative, as it can be in a considerable proportion of old tertiary cases, you can use iodide of potash as a diagnostic test, for it will rapidly clear the " gin-and-midnight voice" of syphilitic laryngitis, and will sometimes consolidate an aneurysm. And, of course, it is safer in these conditions than an arsenical or even penicillin.

And now there is penicillin, that wonderful antibiotic of Fleming's. Have we a cure at last? No one as yet knows. In a disease so protean, so elusive, developing signs so many years later, we of this generation cannot be sure. For if there is anything we can learn from the history I have sketched in this paper it is surely caution. I think, however, we can end on a hopeful note. With the possibilities of an intensive course of penicillin followed by another of arsenic and bismuth, and checked by repeated serum tests, we seem to have reached a turning point in our long fight. Like Moses on Pisgah, perhaps, we may be looking into the Promised Land.

\section{REFERENCES}

Acton, William (1870). "On Prostitution," Second Edition, London, p. 55.

Aphrodisiacus, (1599)، “De Lue Venerca Dialogus," Venice.

Astruc, Jean (1737). "A Treatise on the Venereal Disease," (Barrowby's translation), London.

Auzias-Turenne, J. A. (1853). " De la Syphilisation," Paris, pp. 1-16.

Bell, Benjamin (1793). "A Treatise on Gonorrhœa virulenta and Lues venerea," Edinburgh, Vol. I, pages $1-42$.

Boerhaave, H. (1753). " Tractatio Medico Practica de Lue Aphrodisiaca," Venice. p. 262.

Clare, Peter (1780). "A New and Easy Method of Curing the Lues Venerea." 3rd Edition. London.

Coulson, W. (1869). “ A Treatise on Syphilis,” London.

de Vigo, J. (1540). Opera Domi Joannis de Vigo, Lyons.

Dover, Thomas (1732). "The Ancient Physician's Legacy." Sixth Edition, 1742. London.

Fallopius (1564). “ "De Morbo Gallico," Padua.

Fournier, A. (1890). “" Syphilis et Marriage," Paris. p. 202.

Goodman, H. (1944). "Notable Contributions to the Knowledge of Syphilis," New York. p. 69.

Hutchinson, Jonathan (1861). "On Heredito-syphilitic Struma." Brit. med. J., 1, 515.

Jeanselme, E. (1931). “ “ Histoire de la Syphilis.” p. 284. Lambkin, F. J. (1905). " The Treatment of Syphilis," London. p. 21. 
Lane, J. E. (1896). Brit. med. J. 2, 1702

Lane, J. R., and Gascoyen, G. G. (1867). " Record of Cases Treated in the Lock Hospital by Syphilization." Med.-chir. Trans., 50, 281.

Ricord, P. (1852). “Traité de la Maladie Vénérienne," a translation of John Hunter's "Treatise on Syphilis" with notes by Ricord. Paris. p. 43 .
Sazerac, R., and Levaditi, C. (1921). C. R. Soc. Biol., Paris, $85,30$.

Turner, Daniel (1733). “The Ancient Physician's Legacy Impartially. Surveyed," London. p. 144.

Wagner-Jauregg, J. (1918). "Malaria Impfungen bei Paralyse." Psych. neur. Wschr., 20, 132.

Wallace, William (1835-6). Lancet, $2,5$. (1836-7). Lancet, 2, 534, 615.

\section{DISCUSSION ON THE HISTORY OF THE TREATMENT OF SYPHILIS}

Col. HARRISON asked Mr. Abraham what he thought of the condition of that famous optimist, Dr. Pangloss, mentioned in Voltaire's Candide when Candide met him " all covered over with sores, his eyes half dead, the tip of his nose eaten off, his mouth turned to one side, his teeth black, speaking through his throat, tormented with a violent cough, with gums so rotten, that his teeth came near falling out every time he spit." It seemed to be a description of syphilis with mercurial poisoning.

He thought there might have been some reason for identifying gonorrhœa with syphilis because mercury did have an effect on gonorrhœa. He remembered that during the 1914-18 war an article appeared in a medical journal purporting to show that $100 \mathrm{mg}$. succinimide of mercury injected every other day for three or more doses cured gonorrhrea in about ten days. It did seem to have a rapid effect in reducing the discharge, so that large numbers of cases in his hospital seemed to be cured in less than a fortnight, and his medical officers became quite enthusiastic over it. The alleged cures did not stand a close examination, as a gleet persisted. Nevertheless the effect of the succinimide had been so striking that he had tried a number of mercurial compounds, but when 7,000 cases had been treated on these lines he had concluded that nothing had been gained. He judged that the great reduction of the discharge had been due to the mercury knocking out the reactive power of the tissues, and, in fact, these mercury-treated cases took longer to clear up than those treated on ordinary lines of the period. The action on the reactive power of the tissues might explain the effect of mercurial treatment on the Wassermann reaction in cases that seemed to be Wassermann-fast on arsenical and bismuth treatment.

He remembered before the 1914-18 war a man who had a very profitable pitch in Parliament Square, selling sarsaparilla drinks from a cart. When he was an assistant to the Professor of Medicine at Millbank he treated a patient who was going downhill with syphilis of a lung by giving him Zittmann's Decoction, and the effect was gratifying.

Under the late Col. Lambkin large numbers of patients had been treated with atoxyl at the Military Hospital, Rochester Row, without the slightest damage to their eyesight. Col. Lambkin was a great enthusiast for this form of treatment. He (Col. Harrison) strongly suspected that the damage to the eyes mentioned by $\mathrm{Mr}$. Abraham had been caused by boiling the atoxyl solution.

Dr. David Nabarro said he had recently read the Nonesuch edition of the works of John Wilmot, Earl of Rochester, who died, at the very early age of 33 of a disease which was thought to be syphilis. His mother wrote a-letter to her sister in which these words occurred : " He drinks asses' milk and it digests well with him." At the end of the book there was a note which said that venereal disorders were treated by administering the milk of an ass that had been subjected to inunctions of mercury. Could Mr. Johnston Abraham say when that method came into vogue? It gave the patient the advantage of mercurial inunction without the disadvantages.

He would also confirm Col. Harrison's remarks about atoxyl. He thought that it was used in quite a large number of cases of sleeping sickness, and ordinarily it did not produce symptoms of blindness.

DR. FESSLER pointed out that Mr. Johnston Abraham dealt with the treatment of syphilis by the medical profession. According to leaflets and newspaper advertisements, however, the treatment of venereal diseases by quacks seemed to have been rather widespread in this country during the eighteenth and nineteenth centuries. Of course one did not know what the different pills and medicines contained (? sarsaparilla). It was interesting to note that all the advertisements and leaflets stressed that the drugs were harmless because they did not contain mercury.

The speaker mentioned the treatment of syphilis with malaria. Wagner-Jauregg thought that malaria has a specific influence on syphilis. This idea led Kyrle at Finger's clinic in Vienna in the earlier twenties to carry out a large-scale experiment of treatment of primary and secondary syphilis with malaria. This treatment had soon to be abandoned; nevertheless this experiment had not been without value because it led to the treatment of gonorrhœa with malaria.

MAJOR SCOTT said that just before the war he visited Italy and went to Pompeii, and there he saw certain members which he was told were those of syphilitics, and he saw clavicles and tibiæ which were typical of those seen in congenital syphilis. It was well known that this disease was common in the Roman Army; in fact he thought Nero was supposed to have had it.

DR. RoberT LeES remarked that the modern history of venereal disease was as full of interest as the ancient. He had recently read Janos, a book by Dr. John Plesch in which the author gave interesting studies of Schaudinn, Hoffman, Wassermann, and Ehrlich. He had met some time ago a man who claimed that he was present when Ehrlich received the first reports on the human trials of 